\title{
PENGARUH BUFFER SIZE PADA SISTEM MANET DENGAN MENGGUNAKAN METODE SCHEDULING FIFO Enrico Andriyanto ${ }^{1}$, I.G.A.K Diafari Djuni $\mathrm{H}^{2}$, N.M.A.E.D.Wirastuti ${ }^{3}$ \\ ${ }^{123}$ Program Studi Teknik Elektro, Fakultas Teknik, Universitas Udayana
} Email: enricoandryanto@yahoo.com ${ }^{1}$, igak.diafari@ee.unud.ac.id ${ }^{2}$, dewi.wirastuti@unud.ac.id ${ }^{3}$

\section{ABSTRAK}

MANET atau Mobile Ad Hoc Network merupakan teknologi pada jaringan Ad Hoc yang bersifat mobile dan penggunaanya sendiri sudah sangat luas dikarenakan, node-node pada jaringan ini bergerak secara acak sehingga topologi jaringan ini juga selalu berubah. Pengaturan nilai Buffer size dengan metode Scheduling menggunakan FIFO dapat meningkatkan kualitas pada jaringan ini. Simulasi ini menggunakan OPNET Modeler 14.5 dengan membandingkan pengaruh dari perubahan nilai Buffer Size. Nilai parameter Buffer Size akan diubah-ubah menjadi 20000 bits, 30000 bits, dan 40000 bits dengan menggunakan 20 node. QoS dari kinerja MANET merupakan metode pengukuran tentang seberapa baik jaringan dan merupakan suatu usaha mendefinisikan karakteristik dan sifat dari suatu layanan. Hasil penelitian ini dapat dilihat nilai delay, packet loss dan throughput sudah mendapatkan hasil yang sesuai dan sudah memenuhi standar ITU dengan nilai delay terendah 1,30 millisecond dan nilai throughput dengan 258.096 bps.

Kata Kunci : Buffer size, FIFO, MANET, Scheduling

\begin{abstract}
MANET or Mobile Ad Hoc Network is a technology in Ad Hoc network that is mobile and its own use is very wide because, nodes-nodes in this network is moving randomly so that the network topology is also always changing. Setting Buffer size with Scheduling method using FIFO can improve the quality of this network. This simulation uses OPNET Modeler 14.5 by comparing the effect of the Buffer Size value change. Buffer Size parameter values will be changed to 20000 bits, 30000 bits, and 40000 bits using 20 nodes. QoS of MANET performance is a method of measuring how good a network is and an attempt to define the characteristics and properties of a service. The results of this study can be seen the value of delay, packet loss and throughput have obtained the appropriate results and already meet ITU standards with the lowest delay value of 1.30 millisecond and the value of throughput with 258,096 bps.
\end{abstract}

Keywords: Buffer size, FIFO, MANET, Scheduling

\section{PENDAHULUAN}

MANET atau Mobile Ad-Hoc Network adalah teknologi pada jaringan $\mathrm{Ad}-\mathrm{Hoc}$ yang bersifat mobile dan merupakan sistem wireless mobile node yang dapat bergerak bebas dan secara dinamis dapat dibangun, dioperasikan dan di maintenance oleh mobile node pada jaringan itu sendiri dan tidak bergantung pada infrastruktur yang sudah ada. Sehingga memungkinkan seseorang maupun perangkat dapat berkomunikasi tanpa arsitektur jaringan. Node-node pada jaringan ini bergerak secara acak dan berubah-ubah sehingga topologi jaringan ini juga selalu berubah. Dalam Ad-Hoc network, setiap node yang bertugas merouting data kepada node lain, jadi penentuan node mana yang mengirimkan data dibuat secara dinamis berdasarkan konektivitas dari jaringan itu sendiri.

Metode Scheduling pada antrean FIFO dapat digunakan untuk meningkatkan kualitas pada sistem MANET berupa delay, paket loss, dan throughput. Pada penelitian ini, dilakukan simulasi pengaruh nilai buffer size pada sistem MANET dengan metode Scheduling FIFO dan mengubah-ubah nilai dari buffer size kemudian data akan dibandingkan satu sama lain untuk mengetahui pengaruh dari nilai buffer size tersebut berdasarkan parameter delay, paket loss, dan throughput dalam kualitas layanan. 


\section{KAJIAN PUSTAKA}

\subsection{Mobile Ad-Hoc Network (MANET)}

MANET teknologi pada jaringan Ad-Hoc yang bersifat mobile dan merupakan sistem wireless mobile node yang dapat bergerak bebas dan secara dinamis dapat dibangun, dioperasikan dan di maintenance oleh mobile node pada jaringan itu sendiri dan tidak bergantung pada infrastruktur yang sudah ada. Sehingga memungkinkan perangkat dapat berkomunikasi tanpa menggunakan arsitektur jaringan [2].

\subsection{Buffer Size}

Buffer size merupakan suatu parameter konfigurasi pada WLAN yang berperan penting dalam menentukan kualitas layanan dari suatu jaringan dengan memperhatikan besar pada buffer size, berbagai topologi dapat secara efektif mempertahankan kestabilan dengan delay yang rendah pada saat penggunaan trafik yang padat sekalipun. Buffer size adalah nilai yang diberikan pada parameter WLAN dimana pada saat nilai buffer telah penuh trafik yang datang setelahnya akan dibuang karena buffer tidak dapat menampung lagi data yang masuk dan kemungkinan delay akan terjadi [3].

\subsection{Scheduling}

Proses scheduling merupakan proses keluar masuknya antrean atau queuing dari paket-paket data yang dianggap melebihi batas yang telah ditetapkan. Aturan keluar masuknya data ini bisa dibuat berdasarkan klasifikasi yang bisa dibuat. Scheduling adalah penentuan paket mana yang akan dikirim untuk masuk ke sistem queue dan digunakan untuk mengatur alokasi bandwitdh yang tersedia.

\subsection{First In First Out ( FIFO )}

FIFO merupakan suatu metode antrian yang menggunakan metode persaingan paket. Paket yang pertama masuk akan dilayani terlebih dahulu dan paket yang berikutnya harus menunggu paket pertama selesai. Antrian hanya menggunakan satu antrian sehingga ciri khas dari metode antrian FIFO adalah sangat bergantung pada jumlah paket yang masuk. Semakin banyak antrean yang masuk, maka antrean akan semakin memanjang dan membuat waktu menunggu menjadi lebih lama. Yang memungkinkan antrian akan menjadi sangat panjang tergantung dari paket yang masuk.

\section{METODE PENELITIAN}

Penelitian ini menggunakan 2 skenario. Pada skenario I dilakukan simulasi dengan membandingkan kualitas layanan jaringan Mobile Ad-Hoc Network (MANET) antara yang menggunakan metode scheduling FIFO dan tanpa menggunakan scheduling FIFO. Parameter yang digunakan pada simulasi ditunjukkan seperti pada Tabel 1.

Tabel 1. Parameter pada Simulasi Pertama dan Kedua

\begin{tabular}{|l|c|}
\hline \multicolumn{1}{|c|}{ Parameter } & Nilai \\
\hline Aplikasi & Video COnference \\
\hline Routing Protocol & AODV \\
\hline Jumlah Node & 20 \\
\hline Jenis Node & Mobile Node \\
\hline Mobile Node Speed & $5,6 \mathrm{~m} / \mathrm{s}$ \\
\hline Buffer Size & 40.000 bits \\
\hline Scheduling & FIFO dan tanpa FIFO \\
\hline
\end{tabular}

\section{HASIL DAN PEMBAHASAN}

\subsection{HASIL}

Simulasi perbandingan metode menggunakan FIFO dan tanpa FIFO bertujuan untuk mengetahui kinerja kualitas layanan terbaik pada sistem MANET dengan membandingkan antara yang menggunakan metode scheduling FIFO dan yang tanpa menggunakan metode scheduling FIFO.Dilihat berdasarkan parameter QOS yaitu throughput, delay dan paket loss.

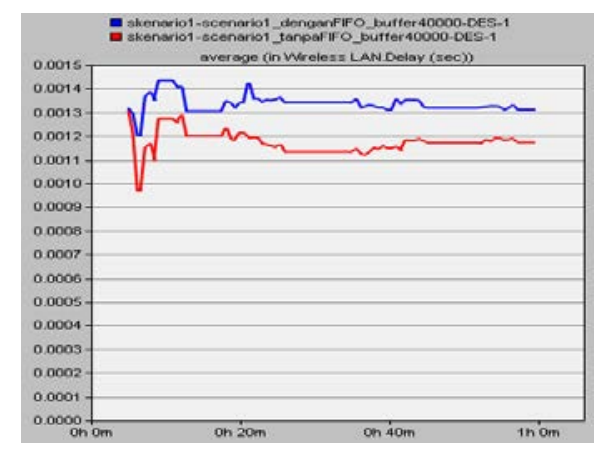

Gambar 1. Simulasi nilai Delay dengan FIFO dan tanpa scheduling FIFO

Gambar 1 pada grafik didapatkan nilai delay dari simulasi yang menggunakan scheduling FIFO memiliki nilai delay yang lebih rendah dibandingkan dengan yang tanpa menggunakan scheduling FIFO, hal ini di- karenakan penggunaan metode scheduling FIFO yang mengatur keluar 
masuknya antrian pada sistem. Hasilnya akan ditunjukkan pada Tabel 2.

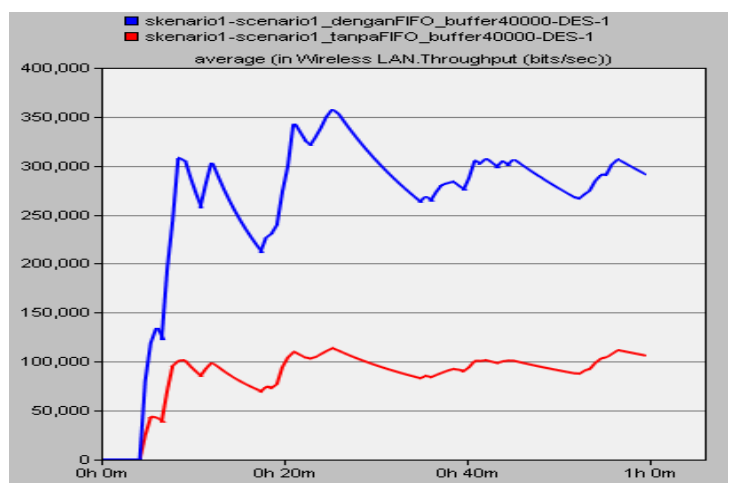

Gambar 2. Simulasi nilai Throughput dengan FIFO dan tanpa FIFO

Gambar 2 pada grafik nilai throughput menunjukkan jumlah rata-rata paket yang berhasil diterima dan dikirim oleh receiver. Pada hasil grafik throughput simulasi yang menggunakan metode scheduling FIFO mendapatkan nilai peningkatan yang lebih besar dibandingkan dengan simulasi yang tanpa menggunakan scheduling FIFO. Berikut hasilnya di tunjukkan pada Tabel 2.

Simulasi perbandingan pengaruh buffer pada 20.000, 30.000, dan 40.000 bits bertujuan untuk mengetahui pengaruh nilai pada buffer size terhadap kinerja kualitas layanan pada sistem MANET dengan membandingkan pada nilai buffer size 20.000, 30.000, dan 40.000 bits yang menggunakan metode scheduling FIFO. Dilihat berdasarkan parameter QOS yaitu throughput, delay dan packet loss.

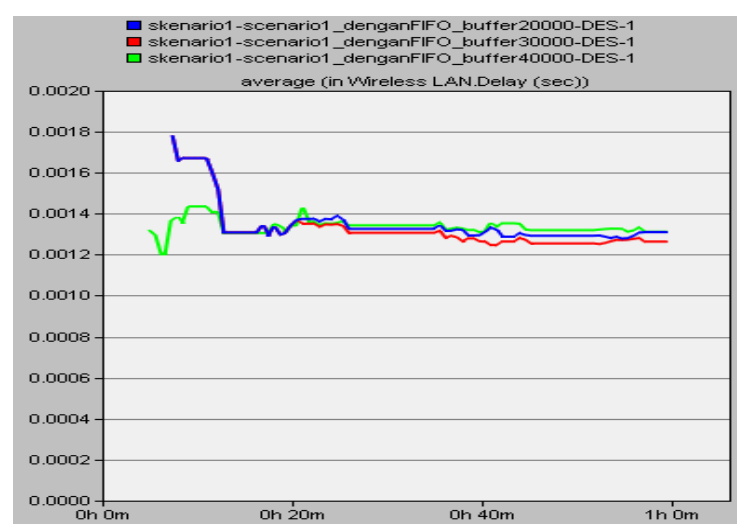

Gambar 3. Delay pada buffer size 20.000, $30.000,40.000$ bits

Hasil grafik Delay pada simulasi dengan buffer size 20.000, 30.000, dan 40.000 bits yang didapat seperti pada Gambar 3. Hasil simulasi pada buffer size 20.000 menunjukkan nilai delay yang sedikit lebih tinggi dari simulasi pada buffer size 30.000 , dan begitupun pada buffer size 30.000 memiliki nilai buffer yang sedikit lebih tinggi

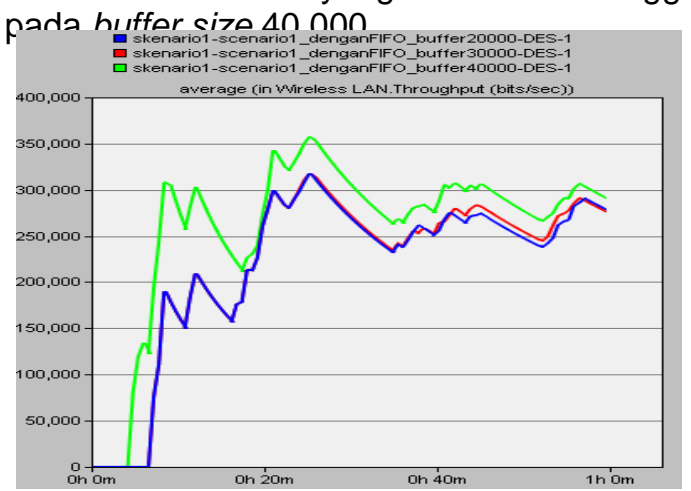

Gambar 4. Throughput pada buffer size 20.000, $30.000,40.000$ bits

Pada Gambar 4 terlihat bahwa nilai throughput pada buffer size yang lebih besar mendapatkan nilai throughput yang lebih tinggi.

\subsection{PEMBAHASAN}

Hasil grafik throughput simulasi yang menggunakan metode scheduling FIFO mendapatkan nilai peningkatan yang lebih besar dibandingkan dengan simulasi yang tanpa menggunakan scheduling FIFO. Berikut hasilnya di tunjukkan pada Tabel 2.

Tabel 2. Hasil nilai delay dan throughput dengan FIFO dan tanpa FIFO

\begin{tabular}{|c|c|c|} 
& $\begin{array}{c}\text { Nilai Rata-rata } \\
\text { Delay(ms) }\end{array}$ & $\begin{array}{c}\text { Nilai Rata-rata } \\
\text { Throughput }\end{array}$ \\
\hline Tanpa FIFO & 1,73 & $85.163 \mathrm{bps}$ \\
\hline Dengan FIFO & 1,33 & $258.096 \mathrm{bps}$ \\
\hline
\end{tabular}

Hasil traffic sent dan traffic received dapat dihitung untuk mendapatkan nilai packet loss. Packet loss pada simulasi yang tanpa menggunakan scheduling FIFO dengan buffer size 40.000 bits menunjukkan terjadinya paket loss yang sangat besar dimana kenaikan terjadi akibat tidak terpenuhinya kapasitas buffer pada wireless LAN sehingga banyak terjadi packet drop dan route error pada saat proses penerimaan paket. Setelah mendapatkan hasil perhitungannya dari kedua simulasi tersebut, simulasi dengan menggunakan scheduling FIFO pada buffer size yang sama mendapatkan hasil yang lebih baik dibandingkan yang tanpa menggunakan scheduling FIFO pada buffer size yang sama. Hasil nya di tunjukkan pada Tabel 3

Tabel 3. Hasil nilai Packet Loss dengan FIFO dan tanpa FIFO 


\begin{tabular}{|c|c|c|}
\hline & Tanpa FIFO & Dengan FIFO \\
\hline $\begin{array}{c}\text { Nilai Rata-rata } \\
\text { Traffic Sent }\end{array}$ & $35.190 \mathrm{bps}$ & $35.023 \mathrm{bps}$ \\
\hline $\begin{array}{c}\text { Nilai Rata-rata } \\
\text { Traffic Received }\end{array}$ & $0,0101 \mathrm{bps}$ & $28.932 \mathrm{bps}$ \\
\hline Packet Loss & $99.99 \%$ & $17,39 \%$ \\
\hline
\end{tabular}

Hasil simulasi pada buffer size 20.000 menunjukkan nilai delay yang sedikit lebih tinggi dari simulasi pada buffer size 30.000, dan begitupun pada buffer size 30.000 memiliki nilai buffer yang sedikit lebih tinggi pada buffer size 40.000. Peningkatan terjadi akibat node yang mengirimkan paket saling menumpuk dan kapasitas buffer yang kurang sehingga mengakibatkan terjadinya packet drop. Packet drop terjadi karena pengirim mencari rute untuk mencapai tempat yang di tuju sehinga delay semakin tinggi, dilihat dari hasil simulasi sudah sangat baik menurut standar ITU-T G.1010 tidak melebihi 150 ms. Berikut hasil nya di tunjukkan pada Tabel 4.

Tabel 4. Delay pada buffer size 20.000, 30.000, 40.000 bits

\begin{tabular}{|c|c|}
\hline Buffer Size & $\begin{array}{c}\text { Nilai Rata-rata Delay } \\
\text { ( } \mathbf{m s})\end{array}$ \\
\hline 20.000 bits & 1,35 \\
\hline 30.000 bits & 1,30 \\
\hline 40.000 bits & 1,30 \\
\hline
\end{tabular}

Gambar 4 terlihat bahwa nilai throughput pada buffer size yang lebih besar mendapatkan nilai throughput yang lebih tinggi. Nilai throughput yang didapat mengalami peningkatan karena seiring dengan besarnya kapasitas buffer size yang diberikan maka nilai throughput akan semakin besar juga. Jika packet sent meningkat sampai pada kondisi tertentu maka throughput mengalami kenaikan, sedangkan pada jumlah paket sent mengalami penurunan maka nilai throughput juga otomatis menurun. Berikut hasil nya di tunjukkan pada Tabel 5 .

Tabel 5. Throughput pada buffer size 20.000, $30.000,40.000$ bits

\begin{tabular}{|c|c|}
\hline Buffer size & Nilai Rata-rata Throughput \\
\hline 20.000 bits & $216.213 \mathrm{bps}$ \\
\hline 30.000 bits & $218.472 \mathrm{bps}$ \\
\hline 40.000 bits & $258.096 \mathrm{bps}$ \\
\hline
\end{tabular}

Simulasi dengan buffer size 20.000, 30.000 , dan 40.000 bits didapatkan hasil dimana semakin kecil buffer size yang digunakan maka akan berdampak terjadinya kenaikan pada nilai packet loss. Dari dua hasil grafik simulasi ini dapat dihitung untuk mendapatkan nilai packet loss, setelah mendapatkan hasil perhitungannya maka mendapatkan hasil yang kurang baik menurut standar yaitu lebih dari $10 \%$. Hal ini dapat terjadi dikarenakan karakteristik dari routing protocol reactive AODV yang tidak cocok dengan penggunaaan metode scheduling FIFO. Tetapi dalam ketiga simulasi tersebut, simulasi dengan buffer size terbesar mendapatkan nilai packet loss terkecil. Ini menunjukan semakin besar pengaturan pada nilai buffer size, maka kemungkinan terjadinya packet loss akan semakin kecil. Berikut hasil nya di tunjukkan pada Tabel 6.

Tabel 6. Packet Loss pada buffer size 20.000, $30.000,40.000$ bits

\begin{tabular}{|c|c|c|c|}
\hline $\begin{array}{c}\text { Buffer } \\
\text { size }\end{array}$ & $\begin{array}{c}\text { Nilai } \\
\text { Rata-rata } \\
\text { Traffic Sent }\end{array}$ & $\begin{array}{c}\text { Nilai } \\
\text { Rata-rata } \\
\text { Traffic } \\
\text { Received }\end{array}$ & $\begin{array}{c}\text { Packet } \\
\text { Loss }\end{array}$ \\
\hline 20.000 & 30.831 bps & 22.936 bps & $25,60 \%$ \\
\hline 30.000 & 30.827 bps & 23.176 bps & $24,82 \%$ \\
\hline 40.000 & 35.023 bps & 28.932 bps & $17,39 \%$ \\
\hline
\end{tabular}

\section{SIMPULAN}

berikut :

Simpulan yang dapat diambil sebagai

1. Untuk sistem MANET yang menggunakan metode scheduling FIFO dan tanpa scheduling FIFO, hasil percobaan terbaik terdapat pada percobaan yang menggunakan metode scheduling FIFO dilihat dari delay, packet loss, throughput. Percobaan dengan menggunakan metode scheduling FIFO mendapatkan nilai delay yaitu 1,30 millisecond, packet loss 17,39\% sedangkan untuk throughput mendapatkan hasil 258.096 bps.

2. Hasil perbandingan buffer size 20.000, 30.000 , dan 40.000 bits yang dilakukan pada 20 mobile node pada layanan Video Conference yang menggunakan $15 \mathrm{fps}$ didapatkan nilai delay dan throughput yang masih memenuhi standar ITU. Simulasi terbaik dilihat dari delay, packet loss, throughput adalah simulasi dengan buffer size 40.000 . Buffer size 40.000 bits mendapatkan hasil delay yaitu 1,30 millisecond, packet loss 17,39 \% sedangkan untuk throughput didapatkan hasil 258.096 bps.

\section{DAFTAR PUSTAKA}

[1] Agung Sediyono, Hendry Rahman. "Perbandingan WFQ dan FIFO pada 
End to end Delay VolP". Teknolnfo, Vol.02 No.1, 2008

[2] Basagni, dkk. 2004. "Mobile Ad-HocNetworking". Institute of Elektrical and Elektronics Engineers.

[3] Kamran Jamshaid, Basem Shihada, Li Xia,and Philip Levis. "Buffer Sizing in 802.11 Wireless Mesh Networks".

MCSE Division, KAUST, Saudi Arabia. 2011

[4] Kurniawan, E. Sani, A. 2015. "Analisis Kualitas Real Time Video Streaming Terhadap Bandwidth Jaringan Yang Tersedia". Konsentrasi Teknik Telekomunikasi, Departemen Teknik Elektro Fakultas Teknik, Universitas Sumatera Utara (USU)

[5] Mwanza, J. Nyirenda, B. 2009. "Performance Evaluation of Routing Protocols in Mobile Ad-Hoc Networks (MANETs)".

[6] Seputra, dkk. 2011. "Perbandingan Kinerja Protokol Aodv Dengan Olsr Pada Manet". Jurusan Teknik Elektro, Fakultas Teknik, Universitas Diponegoro. 